\title{
ドライバの信頼性を考慮したシステム限界時における 鳘報呈示の有効性評価*
}

\author{
鈴木 桂 輔*1, 丸茂 喜 高*2, 山田喜一*3
}

\section{Evaluation on Effectiveness of Warning Presentation in Critical Situation with Consideration of Driver Reliability}

Keisuke SUZUKI*4, Yoshitaka MARUMO and Kiichi YAMADA

${ }^{* 4}$ Department of Mechanical Engineering, Daido Institute of Technology, 10 3 Takiharu cho, Minami ku, Nagoya shi, Aichi, 457-0819 Japan

\begin{abstract}
We investigated drivers' braking behavior when the preceding vehicle unexpectedly brakes, and evaluated the effectiveness of forward vehicle collision warning signals during the use of adaptive cruise control systems. Then, we analyzed the toral error frequency of the man-machine system with consideration of driver's over dependence on the warning signals. Finally, we calculated and evaluated the effectiveness of forward vehicle collision warning signals using this model. In the study, the increase of driver's braking latency or collosion frequency to the preceding vehicle generated by the over dependence on the warning signals was observed. Even though the increase of driver's error frequency was observed, it was revealed that the total error frequency decreased to $1 / 500$ when the warning signals were presented, compared to when they were not given, at a slpeepiness level is high.
\end{abstract}

Key Words : Human Engineering, Human Interface, Intelligent Equipment, Over Reliance, Combined Reliability

\section{1. 锖}

各種センサ技術の向上により，車間距離自動制御 装置 (Adaptive Cruise Control system; ACC) (1) 車 線逸脱防止支援装置 (Lane keeping assistance system） (2) などの, ドライバの運転負荷軽減を目的 とする様々な運転支援装置が実用化されつつある.こ れらの装置によりドライバの運転操作を支援中に，シ ステムに定められた支援範囲を超える状況が発生した 場合には, システムからドライバへ速やかに且つ円滑 に運転を切り替える必要がある.このため, 例えば, 運転支援装置のみでは危険状態を十分に回避できない 「システム限界」の状態に至る可能性がある場合には， ドライバに回避操作を促す警報の呈示が有効であると 思われる。

このシステム限界状態をドライバに警報する機能 は，低覚醒状態のようなドライバの運転注意力が低 下している走行状態において，システム限界状態の 判断を支援するという観点で大きな効果が期待され る. 一方で, 筆者らの先行研究 ${ }^{(3)}$ では, 危険回避の ための操作が必要な状態において，警報が呈示され

\footnotetext{
* 原稿受付 2003 年. 11 月 5 月.

*1 正員, 大同工業大学( 4570819 名古屋市南区滝春町 10 3).

*2 正員（財) 日本自動車研究所( 3050822 つくば市芠間 2530)

*3 (財) 日本自動車研究所.

E mail : ksuzuki (a daido it.ac.jp
}

るまで，ドライバが十分な危険回避操作を行わず， 警報の呈示タイミングの設定によっては，警報を呈 示しない場合と比較して，ドライバの危険回避のた めの操作が遅延するといった運転行動として顕在化 することが示唆されている.

本稿では, 渋滞走行時において先行車両への追従走 行を可能とする低速 ACC をとりあげ，ドライバの制動 操作行動に着目し，警報の呈示による安全性向上への 効果について，定量的に分析することを目的とする. 実験には，（財）日本自動車研究所（以下 JARI と記 す）のドライビングシミュレータを用い，主として， 警報を呈示する条件と呈示しない条件の双方において, 通常覚醒から低覚醒に至る覚醒度別での先行車両の急 減速に対するドライバの制動操作タイミングについて 調查する. 次いで, これらドライバの制動捛作タイミ ングおよび先行車両への衝突の頻度から，運転支援装 置とドライバを統合したシステム全体での衝突の危険 性を意味する統合エラ一確率 (4)，(5) について解析し， システム限界時における警報呈示の有効性について評 価する。

\section{2. システム限界時におけるドライバの正転特性}

2.1 実硂方法 JARI の動摇装置付きドライビン グシミュレータを利用し，低速 $A O C$ を使用して，先行 車両に追従走行する場面を設定した。この走行場面に 
おいて，先行車両を急減速させ，自車両に衝突の危険 性がある状況を模擬し，前方車両衝突警報を呈示した 場合のドライバの運転特性について調査した.

2:1・1 システム限界状況 本実験では，「ドライバ の運転する車両が規定の加速度 $\left(0 \pm 2.5 \mathrm{~m} / \mathrm{s}^{2}\right)$ で先行 車両に追従走行中に, 先行車両がこの規定の加速度よ り大きな加速度で急減速を行い，自車両に衝突の危険 性がある状況」を設定した。

渋滞走行時を模擬して，車速 $0 \sim 12 \mathrm{~m} / \mathrm{s} （ 0 \sim$ 43. $2 \mathrm{~km} / \mathrm{h}$ ) で加減速を繰り返しながら走行中の先行車 両に, 自車両が (1)式に示す車間距離で, 自動追従す る状況を設定した．上記の先行車両が自車両に衝突の 危険性があるシステム限界状況として, 先行車両およ び自車両ともに $12 \mathrm{~m} / \mathrm{s}$ の一定速度で走行を行っている 状況において, 先行車両を減速度 $6 \mathrm{~m} / \mathrm{s}^{2}$ で急減速させ た. 設定したシステム限界状況を図 1 に示す.

また, ブレーキランプ点灯に対する被験者の単純反 応を防ぐため, システム限界状況に至るような急减速 のほか, 緩やかな減速を伴う場面（先行車両の減速度 が $2.5 \mathrm{~m} / \mathrm{s}^{2}$ 以下で, 被験者が制動操作を行わなくても, システム側で十分に減速できるような状況）も設定し た. 被験者には，「先行車両との車間距離が短くなり， 衝突の危除性を感じたら制動操作を行う」ように教示 した，警報の呈示条件に関して，「システム側で十分 な減速を行うことができず，先行車両に衝突の危険性 がある場合に警報が呈示される」とだけ教示し，警報 が即ち制動操作につながるのではなく，ドライバ自ら の判断により危険と感じたタイミングで制動操作を行 う様に教示した.

$\mathrm{D}_{0}=\mathrm{V}_{1} \cdot 2.0+3.0$

$\mathrm{D}_{0}$ : 目標車間距離 $[\mathrm{m}]$

$\mathrm{V}_{1}:$ 自車両の走行速度 $[\mathrm{m} / \mathrm{s}]$

$2.0:$ 車間時間 $[\mathrm{s}], 3.0:$ 安全距離 $[\mathrm{m}]$

2-1-2 前方車両衙突警報本実験では, ドライバ にシステム限界状態を告知する警報として, 前方車両 衝突警報を呈示した。警報呈示アルゴリズムとして, 以下の(2)式に示す Stopping Distance Algorithm を用 いた.

\footnotetext{
$\mathrm{Dw}_{\mathrm{w}}=\mathrm{V}_{1} \cdot \mathrm{T}+\mathrm{V}_{1}^{2} / 2 \mathrm{a}_{1}-\mathrm{V}_{2}^{2} / 2 \mathrm{a}_{2}+3.0 \cdots \cdot(2)$

Dw : 警報発生距離 $[\mathrm{m}]$

$\mathrm{V}_{1}:$ 自車両の走行速度 $[\mathrm{m} / \mathrm{s}]$

$V_{2}:$ 先行車両の走行速度 $[\mathrm{m} / \mathrm{s}]$

$\mathrm{T}$ : 空走時閒 $[\mathrm{s}]$

$\mathrm{a}_{1}:$ 自車両の想定減速度 $\left[\mathrm{m} / \mathrm{s}^{2}\right]$

$\mathrm{a}_{2}:$ 先行車両の想定減速度 $\left[\mathrm{m} / \mathrm{s}^{2}\right]$
}

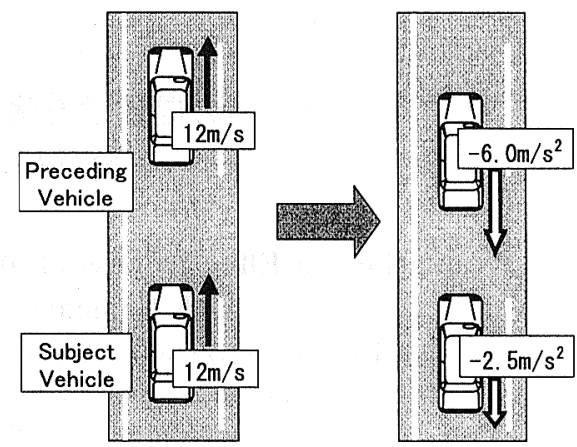

Fig.1 "System limit situation" meaning the critical situation that the vehicle is facing the risk of collision

Table 1 Assumed delay time in the waming condition

\begin{tabular}{|c|c|c|}
\hline Exp.\# & Warning presentation & Assumed delay time \\
\hline 1 & Without & $-\cdots$ \\
\hline 2 & With & $0.6 \mathrm{~s}$ \\
\hline 3 & With & $1.0 \mathrm{~s}$ \\
\hline 4 & With & $1.4 \mathrm{~s}$ \\
\hline
\end{tabular}

自車両の想定减速度 $a_{1}$ および先行車両の想定減速 度 $\mathrm{a}_{2}$ は $5 \mathrm{~m} / \mathrm{s}^{2}$ に設定し, 空走時間 $\mathrm{T}$ として $0.6 \mathrm{~s} ， 1.0 \mathrm{~s}$, $1.4 \mathrm{~s} の 3$ 水準を設定した。空走時間 T はドライバの 反応遅れを考慮したパラメータであり，この值を大き く設定するほど早い時点で警報が呈示されることにな る.つまり，空走時間を $1.4 \mathrm{~s}$ に設定した場合に警報 が最も早い時点で呈示される.

2・1-3 被験者 通勤等の目的で日常的に自動車を 運転している男性ドライバ 16 名, 女性ドライバ 8 名 (年㱓 26〜54 歳，平均年齢：37.04 歳）の合計 24 名 を被験者とした.

\section{2:1:4 実験条件の構成}

（1）正常警報状態でのドライバの制動操作分析 低 速 ACC を作動させた状態での運転に習熟するための練 習走行の後, 警報の有無/警報の呈示タイミング（空 走時間）を組み合わせ，表 1 に示す合計 4 条件を実施 した. これらの実験条件の順序は，できる限り順序効 果を相殺するように，ランダムとした. この走行では, 1 条件あたりの走行時間として設定した約 30 分間の 走行の間で, 被験者が低覚醒の状況に陷ったのを, オ ペレータがドライバの顔の表情を撮影するモニタ画像 から判断して, システム限界状況のイベントを発生さ せた. また, イベントの発生に伴う自車両の停止の後, 制動操作の直前の覚醒度を被験者に主観評価させた。 覚醒度の主観評価の際に被験者に呈示した，覚醒度判 定のための評点の詳細を表 2 に示す. 被験者は, 表 1 に示寸各ヶの条件を 2 回ずつ体験した. 


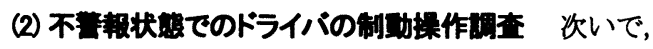
整報システムが不作動となり，システム限界状況にお いて警報が呈示されない不警報状態のドライバの制動 操作について調查した。この調查では, 被酫者を 3 群 に分け，各々の被醉者が一定の空走時間で前方車両衝 突警報が呈示される状況（表 1 に示す実験条件 Exp. \#2，\#3，\#4 と同様のシナリオ）を体験させ，最後 に警報を呈示すると教示している条件下で警報を呈示 しない不警報の状態を体験させた。

\section{2-2 实美拮果}

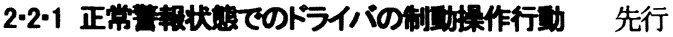
車が堿速を開始した後，被験者が制動操作を開始した時 点での, 車間距離を先行車両と自車両との相対車速で除 して得られる衝突予測時間について集計した。衝突予測 時間の平均值と標準偏差を図 2(b)に示す，横軸は被験者 の覚醒度の主観砰価值，䋛軸は制動開始タイミングを示 す.なお，図2(a)は，先行車両が減速を開始したタイミ ング (0s) からの衝突予測時間の一例（空走時間 $\mathrm{T}$ が 1.0s の場合）を示し，被輖者が制動操作を開始したタイ ミングの衝突予測時間の定義を示している. 制動操作を 開始したタイミングでの衝突予測時間を集計した結果が 図 2(b)である. 本実験での走行条件では，先行車両が減 速を開始して, $\mathrm{T}=0.6 \mathrm{~s}$ の場合では $3.0 \mathrm{~s}$ 後, $\mathrm{T}=1.0 \mathrm{~s}$ の場合 では $2.1 \mathrm{~s}$ 後, $\mathrm{T}=1.4 \mathrm{~s}$ の場合では $1.1 \mathrm{~s}$ 後に警報が呈示さ れている. 空走時間 T が長い場合は前方車両衝突警報の 呈示タイミングが早くなり，これに伴い被験者の制動開 始タイミングが早く（衝突予測時間が長く）なっている ことが分かる. 例えば，覚醒度の主観砰価值が 1 を示す 条件において，空走時間 T が $0.6 \mathrm{~s}, 1.0 \mathrm{~s}, 1.4 \mathrm{~s}$ と増加寸 るにつれて，制動開始タイミングの平均值は，衝突予測 時間に換算して $1.7 \mathrm{~s}$ (1) ，2.0s (2) ，2.3s (3) と 延長している. また, 前方車両衝突整報を呈示しない場 合の制動開始タイミング (4) と比較すると，空走時間 T が 1.4s の場合における制動開始時の衝突予測時間の 平均値（3）は延長しており（制動開始タイミングが早 くなる），空走時間 T が 0.6s の場合（1) では短縮し ている（制動開始タイミングが遅くなる）ことが分かる. 更に，前方車両衙突警報を呈示しない走行条件（白丸： ○）と比較すると，前方車両衝突警報を呈示する走行条 件では，覚醒度の低下に伴う制動開始タイミングの遅延 の程度が小さいことが分かる. 例えば，覚醒度の主観産 価值が 1 と 4 での調查結果を比較した場合, 前方車両衝 突警報を呈示しない走行条件では，制動開始タイミング が衝突予測時間に換算して 2.2s（4)）から $1.1 \mathrm{~s}$ 短縮し $1.1 \mathrm{~s}$ (5) を示している. この覚醒度の主観評価値が 4 を示した走行条件においては，制動操作開始タイミング
Table2 Subjectiveratimgs for sleepiness level

\begin{tabular}{|c|c|l|}
\hline Rating & Sleepiness & \multicolumn{1}{|c|}{ Concrete sleepiness level } \\
\hline 1 & Not at all & No sleepiness, fully conscious \\
\hline 2 & $\begin{array}{c}\text { Slightly } \\
\text { sleepy }\end{array}$ & A little sleepiness, no influence on driving \\
\hline 3 & Sleepy & $\begin{array}{l}\text { Obvious sleepiness, manage to drive } \\
\text { somehow }\end{array}$ \\
\hline 4 & $\begin{array}{c}\text { Very } \\
\text { sleepy }\end{array}$ & $\begin{array}{l}\text { Dangerous sleepiness, generally unable to } \\
\text { drive }\end{array}$ \\
\hline
\end{tabular}

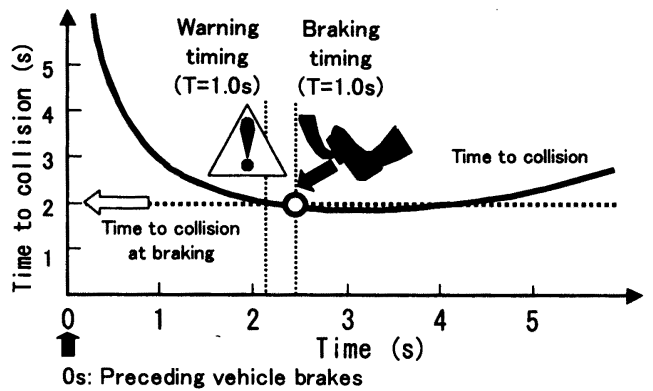

(a) Definition of Time to collision at braking operation

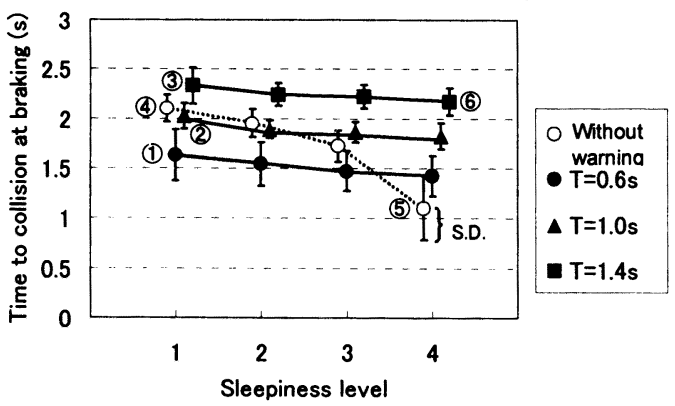

(b) Braking timing in each waming condition

Fig.2 Time to collision at braking operation $(n=48)$

の遅れが著しく，8名の被験者のうち 1 名は先行車両に 衝突している.これに対して，例えば，空走時間 T が 1.4s の条件において前方車両衝突警報を呈示した場合に は，制動開始タイミングは衝突予測時間に換算して 2.3s

（3） から $2.2 \mathrm{~s}$ (6) と変化しているものの, その変化 量は $0.1 \mathrm{~s}$ の短縮に留まり，警報を呈示しない場合と比 較して制動摷作タイミングの遅延の程度が小さい，早期 タイミングにおける，警報呈示の有效性が示されている.

実験を開始する前の被験者に対する教示として, 前方 車両衝突警報が呈示された直後に制動㨐作を行うのでは なく, 自らの判断で危険と感じた時点で制動操作を行う ように教示した. しかしながら, 被験者の制動操作タイ ミングは，警報の呈示タイミングに影響される傾向が観 察された. システム限界が発生した状況において, 被験 者は先行車両の减速のみでは無く，警報の呈示も同様に 制動捛作の判断基淮としていたものと推察される. 


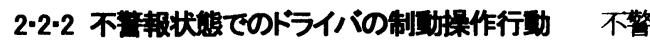

報状態における，ドライバの制動開始タイミングにいて 分析した.「警報無し」，「警報有り」 $\Rightarrow$ 「不警報」に 至る一連の被験者の制動掜作タイミングを，その一例と して，覚醒度が低下していない評価值が 1 の状態につい て空走時間別に集計した結果を図 3 に示す。この警報な しとは，警報装置が作動していない状況，不警報とは， 警報装置が作動していると教示している状態で，故障等 により警報が呈示されない状況を意味する. なお，今回 の実験では，「警報有り」 $\Rightarrow$ 「不警報」の走行と，「警 報なし」の走行は，順序効果を低减するために，被験者 毎にランダムとしており，これらの条件間での順序効果 は低减できているものと考える.

図 3 に示すように，不警報状態における制動開始タイ ミングは，警報の呈示タイミングが最も遅い空走時間 $\mathrm{T}=0.6 \mathrm{~s}$ の走行条件（7)）において最も遅延している（衝 突予測時間が短縮している）。また，この空走時間 $\mathrm{T}=0.6 \mathrm{~s}$ の走行条件においては, 制動操作開始タイミング の遅れが著しく,8 名の被験者のうち 1 名は先行車両に 衝突している.

今回の実験では，各々の被験者は，不警報状態（Miss warning）を体験する前に，正常警報状態（With warning）を体験している. この正常警報状態において, 空走時間 $\mathrm{T}=0.6 \mathrm{~s}$ の走行条件では，警報の呈示タイミン グが非常に遅い，例えば，空走時間 $\mathrm{T}=1.4 \mathrm{~s}$ の走行条件 では，先行車が減速を開始してから $1.1 \mathrm{~s}$ 後に警報が呈 示されるのに対して, 空走時間 $\mathrm{T}=0.6 \mathrm{~s}$ の走行条件では, 3. Os 後に警報が呈示されている. この先行車が減速を開 始してから 3.0s 後という遅い警報の呈示に習熟してい る走行状態において不警報 (Miss warning) となった走行 状況おいて，被験者は先行車両の急减速を十分に認識す ることができず，制動開始タイミングが遅延したものと 推測される.

2-2.3 先行車両への征突率 以上の調査実験で得ら れた，覚醒度と警報呈示タイミング別での先行車両への 衝突率について集計した結果を表 3 に示寸．前方車両衝 突警報を呈示しない走行条件では，覚醒度の主観評価値 が 4 を示す覚醒度が非常に低下した状態において, 12.5\%の頻度で先行車両に衝突している. これに対し, 警報を呈示寸る走行条件では，主観評価值が 4 を示す状 態においても, 先行車両への衝突は発生していない(衝 突率 : 0\%) . 被験者の覚醒度が非常に低下した状態に おいて, 前方車両衝突警報の呈示は, 被験者の制動操作 を促すうえで有効であったことが分かる. また一方で， 空走時間 $\mathrm{T}=0.6 \mathrm{~s}$ で不警報となる走行条件では, 制動操 作開始タイミングの遅れが著しく，12.5\%の衝突率を示

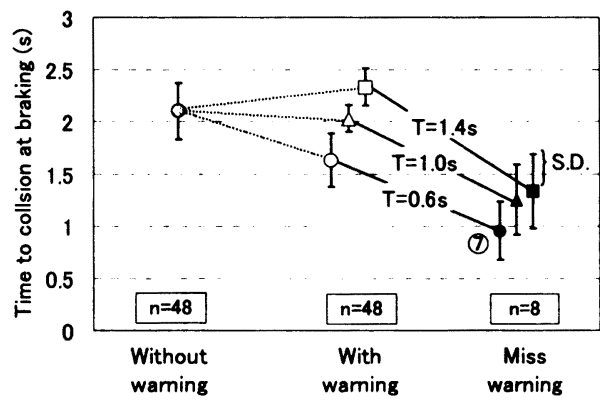

Fig3 Drivers' braking latency at each warning condition (Normal arousal level)

Table 3 Frequency of the collisionateach waming/sleepinesscondition

\begin{tabular}{|c|c|c|c|c|}
\hline & \multicolumn{4}{|c|}{ Slegpinesteved } \\
\hline & Level I & Level2 & Level3 & Level4 \\
\hline Whatwaming & $0 \%$ & $0 \%$ & $0 \%$ & $125 \%$ \\
\hline With waming $\mathrm{T}=0.6 \mathrm{~s}$ & $0 \%$ & $0 \%$ & $0 \%$ & $0 \%$ \\
\hline Wthwaming $\mathrm{T}=1.0 \mathrm{~s}$ & $0 \%$ & $0 \%$ & $0 \%$ & $0 \%$ \\
\hline Whth waming $\mathrm{T}=1.4 \mathrm{~s}$ & $0 \%$ & $0 \%$ & $0 \%$ & $0 \%$ \\
\hline Misswaming $(\mathrm{T}=0.6 \mathrm{~s})$ & $125 \%$ & - & - & $25.0 \%$ \\
\hline Miss waming $(\mathrm{I}=1.0 \mathrm{~s})$ & $0 \%$ & - & - & $25.0 \%$ \\
\hline Misswaming $(T=1.48)$ & $0 \%$ & - & - & $125 \%$ \\
\hline
\end{tabular}

- : Not measured

した. 警報システムを使用中において何らかの原因で警 報が呈示されない場合には，ドライバは先行車両の减速 を十分に認識することができず，先行車両に衝突する危 険性があるものといえる.

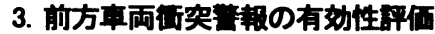

本章では, 前章のドライバの制動操作行動の調査 結果を踏まえて, 運転支援システムの支援を受けた場 合のシステムとドライバの統合エラー確率を解析する モデルを用い，低速 $\mathrm{A} C$ のシステム限界時における前 方車両衝突警報の有效性について分析した.

\section{1 ドライパ・システム統合エラ一磼事検期モデル}

運転支援システムを使用中におけるエラ一確率は，運 転支援システムとドライバとの相互の関係を考虑して 解析すべきであると考える. 本項では, 山田 ${ }^{(4)} \cdot{ }^{(5)} に$ より提案された手法を参考に, 前方車両衝突警報装置 を使用中における統合エラ一確率について分析した。 前方車両衝突警報装置を例とする場合のドライバ・シ ステム統合エラーの解析モデルを図 4 に示寸.

このモデルでは，ドライバと運転支援システムが共 にエラーを起こした場合に事故が発生すると定義して いる. 図中では, (1), (2)の面積の合計が, 共にエラー を起こす場合のエラー確率を示している．また，本稿 
では, エラー確率の定義を, 先行車の急减速時などの 危険な状況が発生する回数に対する衝突が発生する回 数の割合（衝突回数／危険事象発生回数）とした

(注 : 表 3 の割合は, 衝突回数/実験回数でありこの 值と対応している）。

3:1:1 (1)の面積で表されるエラ一確率 (1)の面積 は, ドライバとシステムのエラーが重なった場合に発 生するエラー確率を示している，例えば，システムが 不警報となった場合に，ドライバはこれに気づいたに もかかわらず，制動操作が遅れるなどの理由で先行車 両に衝突する確率を示している。 また，このエラ一確 率は, 横軸に示すドライバの操作エラー確率 Ed に, 縦軸に示すシステムのエラー確率 Es を掛け合わせる ことにより算出することができる.この(1)面積で表 されるエラー確率は，(3)式のようになる．具体的な 算出例は，以下の項に示す.

$\mathrm{Eds} 1=\mathrm{Ed} \cdot \mathrm{Es}$

3:1.2 (2)の面積で表されるエラ一確率 (2)の面積 は, システムがエラーを起こした場合に，ドライバの システムへの過信などにより，これをドライバが補完 できないとき発生するエラー確率の，(1)の面積で表さ れるエラ一確率からの増分を示している。 また，この エラー確率忙，横軸に示すシステム不作動時における ドライバの操作エラー確率の正常警報時における操作 エラー確率からの增分 $\mathrm{a}$ に, 縦軸に示すシステムのエ ラー確率 Es を掛け合わせることにより算出すること ができる，この(2)の面積で表されるエラ一確率は，

(4)式のようになる.

Eds2 $=\mathrm{a} \cdot$ Es ・・(4)

3.1.3 パラメータの詳細 横軸は, ドライバの信 頼性を，操作エラー確率と正常操作確率に分割して示 している.このドライバ操作エラー確率 (Ed+a) と正 常操作確率（1-Ed-a）との和は 1.0 である. 縦軸は, 警報装置の信頼性を，エラー確率（Es+b）之正常作動 確率 $(1-E s-b)$ に分割して示している。 このシステムの エラ一確率と正常作動確率との和は 1.0 である. それ ぞれのパラメータの詳細を以下に示す.

Ed : ドライバの操作エラー確率（先行車の急減速時な ど危険な状況が発生する回数に対する，衝突が発 生する回数の割合）を示す.

Es : 警報装置が不作動となる累積時間の，累積走行時 間に対する割合を示す

a ：a は，システム不作動時におけるドライバの操作 エラー確率の正常警報時におけるドライバの操作 エラー確率からの増分を意味する.

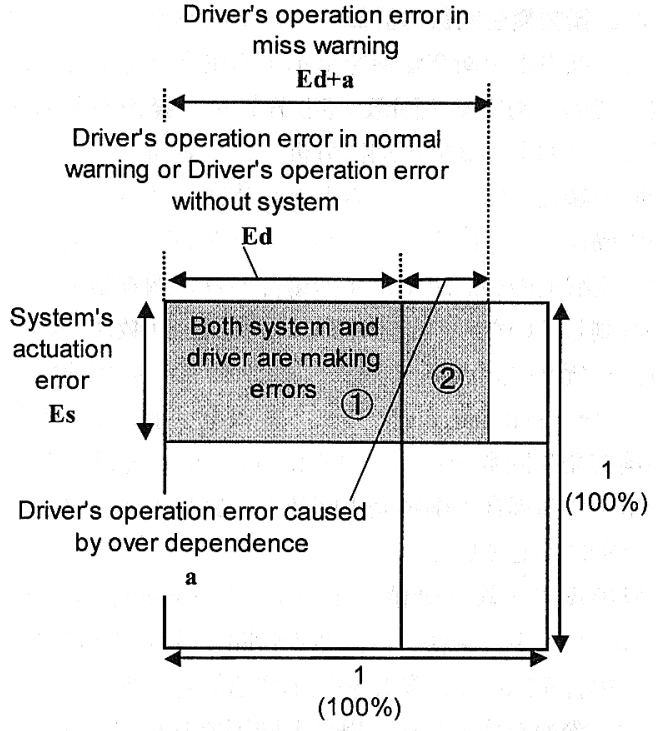

Fig.4 Model for the analysis of combined error frequency

3:1.4 衝突発生回数への換算 本稿では, エラー確 率を, 衝突回数／危険事象発生回数と定義している. 従って，実際に衝突が発生する回数に換算するために は，危険事象が発生する頻度（通常は単位時間あた り）を掛け合わせる必要がある. 現実の事象を考える と, 衝突発生回数で評価したほうが直感的に分かりや すいことから，以下では単位時間あたりの衝突発生回 数 $[$ 回 $/ \mathrm{h}]$ に換算して評価する.

\section{2 衏咨発生回数の評価}

\subsection{1 パラメ一タの推定}

(1) ドライバの操作エラ一確率ドライバの操作エラ 一確率を意味するパラメータ Ed として, 前章の調査 結果より得られた, 表 3 に示す值 (Without warning / With warning におけける衝突率) を用いる. 同様に, ド ライバのエラー確率を意味するパラメータ $\mathrm{Ed}+\mathrm{a}$ とし て, 表 3 に示寸值 (Miss warning における衝突率) を 用いる.

（2）システム限界状況が発生する頻度 システム限界 状況（危険事象）が発生する嚬度としては，東京都の 都心環状線において, 先行車両の減速度が $2.5 \mathrm{~m} / \mathrm{s}^{2}$ 以 上となる状態の累計時間の単位走行時間に対する回数 を計測し，1.5[回／h] を代表値とした。

（3）警報装置のエラ一確率 警報装置が不作動とな る累積時間の，累積走行時間に対する割合を示すパラ メータES としては, 先行車両の不検出の確率を考慮 した，本稿では，車両の前端部分に設置したレーザレ 一ダを用いて同様に東京都の都心環状線において計測

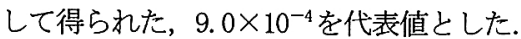


3-2.2 征突発生回数の計算 以上のパラメータを用 いて，前方車両衝突警報を呈示する場合と呈示しない 場合での, 衝突発生回数 [回/h] を, 警報の呈示夕 イミングおよび覚醒度別に分析した（表 4）。 なお, 今回の調査では, システム不作動時における, ドライ バの操作エラー確率を示すパラメータ $\mathrm{Ed}+\mathrm{a}$ に関して は，覚醒度の評点が 1 と 4 の場合のみの調查結果かし か計測していない. このため, 衝突発生回数について は, 覚醒度の評点が 1,4 の場合のみについて分析し た.「Without warning」では，警報を呈示しない場合 の衝突発生回数を示し「「ith warning」では, 撆報 を呈示する場合の衝突発生回数を, 警報の呈示タイミ ング別に示している.

覚醒度の主観評価値が 1 （No sleepiness，全く眠 くない）の走行条件では, 空走時間 $\mathrm{T}$ を $0.6 \mathrm{~s}$ に設定 した場合を除いて，撆報を呈示する場合の衝突発生回 数は, 警報を呈示しない場合と同等で非常に小さくな る.これに対して, 覚醒度の主観評価評点が 4 (非常

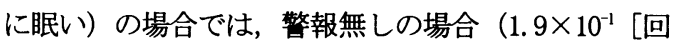
/h]）よりも警報を呈示する場合の衝突発生回数 （T=0.6s，1.0s の場合 : $3.4 \times 10^{-4}$ [回/h]， $\mathrm{T}=1.4 \mathrm{~s}$ の場合 : $1.7 \times 10^{-4}$ [回/h] ）は低下寸る.この衝突 発生回数は, 例えば, 評点が 4 の状態 (Dangerous sleepiness, 通常なら運転を諦めるほどに覚醒度が低 下した状態）では，警報を呈示しない場合では，約 5.3 時間に 1 度の確率で前方車両に衝突する可能性が るのに対して，警報を呈示した場合では，約 2,900 時 間に一度の確率にまで低下することを意味している。

警報を呈示することにより，衝突の危険性が 1/500 程 度以下まで低下寸ることが分析結果より分かる．この 調査結果から, 前方車両衝突警報の有効性について判 断すると，警報装置に対する依存がもたらすドライバ 信頼性の低下を考慮しても，覚醒度の低下が著しい状 態では，警報の有効性は極めて高いものと思われる.

本稿において示したドライバとシステムとの統合 エラー確率モデルによる解析手法により, 前方車両衝 突警報の有效性について定量的な分析を害施できるも のと考える. また, 本稿でのエラー確率の解析には, 各々の条件において, 通常警報時では 24 名 $\times 2$ 試行 の合計 48 試行, 不警報時では 8 名 $\times 1$ 試行の合計 8 試行の調査結果に基づいている. 統合システムエラー 確率のより定量的な解析を行うためには，実験誤差等 を最小限に抑えるため, より多くの調査結果 ( $\mathrm{n}$ 数) を取得する必要があるものと思われる.
Tablo4 Calculation results regarding the collision frequency

\begin{tabular}{|c|c|c|}
\hline & $\begin{array}{c}\text { Sleepiness Level 1 } \\
\text { Nosleepines fully } \\
\text { conscious }\end{array}$ & $\begin{array}{c}\text { SleopinessLevel 4 } \\
\text { Dangerous } \\
\text { sleepiness generally } \\
\text { unabletodrive }\end{array}$ \\
\hline Withoutwaming & 0 & $1.9 \times 10^{-1}$ \\
\hline $\begin{array}{c}\text { Withwaming } \\
\text { T=0.6s }\end{array}$ & $1.7 \times 10^{-4}$ & $3.4 \times 10^{-4}$ \\
\hline $\begin{array}{c}\text { Withwaming } \\
\text { T=1.0s }\end{array}$ & 0 & $3.4 \times 10^{-4}$ \\
\hline $\begin{array}{c}\text { Withwaming } \\
\text { T=1.4s }\end{array}$ & 0 & $1.7 \times 10^{-4}$ \\
\hline
\end{tabular}

\section{4. まとめ}

\section{4-1 システム限界時におけるドライバの国伝特性}

システム限界が発生した状況において, 被験者は先行 車両の减速のみを制動操作の判断基準としているので は無く, 前方車両衝突警報の呈示タイミングも同様に 制動操作の判断基準としている状況が観察された. ま た，何らかの原因で警報システムが不作動の状況に陥 った場合には, タイミングの設定によっては, 先行車 両に衝突する危険性があることが示唆された.

4-2 籍報星示の有效性評価覚醒度が低下して いる状態では, 警報無しの場合の衝突発生回数（1.9 $\times 10^{-1}[$ 回 $\left./ \mathrm{h}]\right)$ よりも，警報を呈示する場合の衝突 発生回数（T=0.6s, $1.0 \mathrm{~s}$ の場合 : $3.4 \times 10^{-4}[$ 回 $/ \mathrm{h}]$,

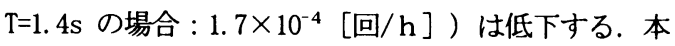
調查において実施したドライバとシステムとの統合 エラ一確率の解析手法により, 前方車両衝突警報の 有効性について定量的な分析を行うことができるも のと考える.

\section{参考文献}

(1) 山田喜一：車間距離制御システムの研究，自動車 技術会論文集，Vol.31No.4，61/66，2000

(2) P.Leelavansuk, K.Shitamitsu, H.Mouri, M.Nagai: Study on Cooperative Control of Driver and Lane Keeping Assistance System, $6^{\text {th }}$ International Symposium on Advanced Vehicle Control 2002, 219/224, 2002

（3）鈴木桂輔, 丸茂喜高 : システム限界時におけるド ライバの運転特性, 日本機械学会論文集（C 編） 69 巻 685 号, 207/212, 2003

(4) 山田喜一：運転支援システムの開発事例, IATSS Review, Vol.24, No.2, 47/52, 1998

(5) 山田喜一ほか：走行支援システム（AHS）の安全 設計指針の研究，自動車技術会論文集，Vol.31， No.4, 55/60, 2000 